\title{
ANALISIS FAKTOR-FAKTOR PENENTU KINERJA KEUANGAN DAN KUALITAS AKTIVA PRODUKTIF (KAP) TERHADAP KINERJA KEUANGAN PADA PT. BANK PERKREDITAN RAKYAT (BPR) CENTRAL ARTHA REZEKI, TANGERANG
}

\author{
Wahyudi \\ Program Magister Manajemen \\ Sekolah Tinggi Ilmu Ekonomi Bisnis Indonesia, Jakarta \\ Sutardi \\ Dosen STIE Bisnis Indonesia, Jakarta \\ dan \\ Muhammad Zilal Hamzah \\ Dosen STIE Bisnis Indonesia, Jakarta \\ Paper dipresentasikan pada Seminar Nasional \\ Financial Inclusion to Achieve Sustainable Development in Indonesia, \\ diselenggarakan oleh FEB Usakti dan Badan Otoritas Jasa Keuangan (OJK) Indonesia, \\ 28 April 2016 di Jakarta
}

\begin{abstract}
This study, entitled the influence of Non Performing Loan (NPL), Operational Costs of Operating Income (BOPO), Capital Adequacy Ratio (CAR), Loan to Deposit Ratio (LDR), Net Interest Margin (NIM), Debt To Equity Ratio (DER), Debt to Total Assets Ratio (DAR), Cash Ratio (CR), and Quality of Earning Assets (KAP) toward Financial Performance at PT. Bank Perkreditan Rakyat (BPR) Central Artha Rezeki, Tangerang. The aim of this study was to determine the effect of Non Performing Loan (NPL), Operational Costs of Operating Income (BOPO), Capital Adequacy Ratio (CAR), Loan to Deposit Ratio (LDR), Net Interest Margin (NIM), Debt To Equity Ratio (DER), Debt To Total Assets Ratio (DAR), Cash Ratio (CR), and Quality of Earning Assets (KAP) toward Financial Performance. The research method using multiple regression and correlation analysis. Research found results that partially only variable Cash Ratio (CR) that significantly influence financial performance while simultaneously Non Performing Loan (NPL), Operational Costs of Operating Income (BOPO), Capital Adequacy Ratio (CAR), Loan to Deposit Ratio (LDR), Net Interest Margin (NIM), DebtToEquity Ratio (DER), Debt To Total Assets Ratio (DAR), Cash Ratio (CR), and Quality of Earning Assets (KAP) significantly affects financial performance.

Keywords: Non Performing Loan (NPL), Operational Costs of Operating Income (BOPO), Capital Adequacy Ratio (CAR), Loan to Deposit Ratio (LDR), Net Interest Margin (NIM), Debt To Equity Ratio (DER), Debt To Total Assets Ratio (DAR), Cash Ratio (CR), Quality of Earning Assets (KAP), Financial Performance.
\end{abstract}

Abstrak: Penelitian ini berjudul pengaruh Non Performing Loan (NPL), Biaya Operasional Terhadap Pendapatan Operasional (BOPO), Capital Adequacy Ratio (CAR), Loan To Deposit Ratio (LDR), Net Interest Margin (NIM), Debt To Equity Ratio (DER), Debt To Total Asset Ratio (DAR), Cash Ratio (CR) dan Kualitas Aktiva Produktif (KAP) terhadap Kinerja Keuangan pada PT. Bank Perkreditan Rakyat (BPR) Central Artha Rezeki, Tangerang. Tujuan dari penelitian ini adalah untuk mengetahui pengaruh Non Performing Loan (NPL), Biaya Operasional Terhadap Pendapatan Operasional (BOPO), Capital Adequacy Ratio (CAR), Loan To Deposit Ratio (LDR), Net Interest Margin (NIM), Debt To Equity Ratio (DER), Debt To Total Asset Ratio (DAR), Cash 
Ratio (CR), dan Kualitas Aktiva Produktif (KAP) terhadap Kinerja Keuangan. Metode penelitian menggunakan metode analisa regresi dan korelasi berganda. Hasil penelitian ditemukan hasil bahwa secara parsial hanya variable Cash Ratio (CR) yang berpengaruh signifikan terhadap Kinerja Keuangan sedangkan secara simultan Non Performing Loan (NPL), Biaya Operasional Terhadap Pendapatan Operasional (BOPO), Capital Adequacy Ratio (CAR), Loan To Deposit Ratio (LDR), Net Interest Margin (NIM), Debt To Equity Ratio (DER), Debt To Total Asset Ratio (DAR), Cash Ratio (CR), dan Kualitas Aktiva Produktif (KAP) berpengaruh signifikan terhadap Kinerja Keuangan.

Kata Kunci: Non Performing Loan (NPL), Biaya Operasional Terhadap Pendapatan Operasional (BOPO), Capital Adequacy Ratio (CAR), Loan To Deposit Ratio (LDR), Net Interest Margin (NIM), Debt To Equity Ratio (DER), Debt To Total Asset Ratio (DAR), Cash Ratio (CR), Kualitas Aktiva Produktif (KAP), Kinerja Keuangan.

\section{PENDAHULUAN}

Industri Perbankan memegang peranan penting bagi pembangunan ekonomi sebagai Financial Intermediary atau perantara pihak yang kelebihan dana dengan pihak yang membutuhkan dana. Menurut Ali (2006), bank didefinisikan sebagai lembaga keuangan yang memiliki izin usaha untuk beroperasi sebagai bank, yaitu menerima penempatan dana-dana yang dipercayakan masyarakat kepada bank tersebut, memberikan pinjaman kepada masyarakat dan dunia usaha pada umumnya, memberi akseptasi atas berbagai bentuk surat utang yang disampaikan pada bank tersebut serta menerbitkan cek.

Terjadinya krisis moneter di Indonesia sejak pertengahan tahun 1997 membawa dampak pada sektor perbankan. Krisis moneter mengakibatkan banyaknya bank yang mengalami kredit macet. Hal tersebut mempengaruhi iklim investasi pasar modal dibidang perbankan baik secara langsung maupun tidak langsung.

Kinerja perusahaan dapat diukur dengan menganalisa dan mengevaluasi laporan keuangan. Informasi posisi dan kinerja keuangan dimasa lalu seringkali digunakan sebagai dasar untuk memprediksi posisi keuangan dan kinerja dimasa depan dan hal-hal lain yang langsung menarik perhatian pemakai seperti pembayaran deviden, upah, pergerakan harga sekuritas dan kemampuan perusahaan untuk memenuhi komitmennya ketika jatuh tempo. Seementara itu, kinerja perbankan dapat diukur dengan menggunakan rata-rata tingkat bunga pinjaman, rata-rata tingkat bunga simpanandan profitabilitas perbankan. Lebih lanjut lagi dalam penelitiannya menyatakan bahwa tingkat bunga simpanan merupakan ukuran kinerja yang lemah dan menimbulkan masalah, sehingga dalam penelitiannya diisimpulkan bahwa profitabilitas merupakan indikator yang paling tepat untuk mengukur kinerja suatu bank

Beberapa faktor yang bepengaruh terhadap kinerja bank adalah CAR, BOPO, NPLdan LDR. Capital Adequacy Ratio (CAR) adalah rasio keuangan yang berkaitan dengan permodalan perbankan dimana besarnya modal suatu bank akan berpengaruh pada mampu atau tidaknya suatu bank secara efisien menjalankan kegiatannya. Non Performing Loan (NPL) merupakan rasio keuangan yang berkaitan dengan risiko kredit, dimana risiko kredit adalah risiko dari kemungkinan terjadinya kerugian bank sebagai akibat dari tidak dilunasinya kembali kredit yang diberikan kepada debitur. Sementara Loan to Deposit Ratio (LDR) merupakan rasio yang mengukur kemampuan bank untuk memenuhi kewajiban yang harus dipenuhi. Debt to total asset ratio (DAR) merupakan rasio antara total hutang (total debts) baik hutang jangka pendek (current liability) dan hutang jangka panjang (long term debt) terhadap total aktiva (total assets) baik aktiva lancar (current assets) maupun aktiva tetap (fixed assets) dan aktiva lainnya (other assets). 
Cash ratio merupakan salah satu ukuran dari rasio likuiditas (liquidity ratio) yang merupakan kemampuan perusahaan memenuhi kewajiban jangka pendeknya (current liability). Kualitas Aktiva Produktif (KAP) merupakan salah satu faktor penentu kesehatan Bank. KAP sangat berperan dalam memperoleh tingkat pendapatan bagi Bank.

Berdasarkan latar belakang masalah di atas, maka penulis mengambil judul penelitian "Pengaruh Non Performing Loan (NPL), Biaya Operasional terhadap Pendapatan Operasional (BOPO), Capital Adequency Ratio (CAR), Loan to Deposit Ratio (LDR), Net Interest Margin (NIM), Debt to Equity Ratio (DER), Debt to Total Asset Ratio (DAR), Cash Ratio (CR), dan Kualitas Aktiva Produktif (KAP) terhadap Kinerja Keuangan pada PT. Bank Perkreditan Rakyat (BPR) Central Artha Rezeki, Tangerang”.

\section{TINJAUAN TEORI}

\subsection{Pengertian Manajemen.}

Pengertian manajemen menurut Williams (2001) adalah menyelesaikan pekerjaan melalui orang lain. Seorang manajer bukanlah mengerjakan semua pekerjaan sendiri, tetapi bekerja melalui orang-orang yang memiliki kemampuan-kemampuan teknis di lapangan. Sedangkan menurut Stoner (1996), manajemen adalah suatu proses perencanaan, pengorganisasian, kepemimpinan, dan pengendalian supaya anggota organisasi menggunakan semua sumber daya organisasi untuk mencapai tujuan yang telah ditetapkan. Sementara itu menurut Hasibuan (2004), manajemen adalah suatu proses khas yang terdiri atas tindakan-tindakan perencanaan, pengorganisasian, penggerakkan dan pengendalian untuk menentukan serta mencapai tujuan melalui pemanfaatan sumber daya manusia dan sumber daya lainnya. Ini dikenal sebagai fungsi-fungsi manajemen. Lebih lengkap, fungsi-fungsi manajemen menurut Terry dalam Athoillah (2010 : 95-118), dapat diuraikan sebagai berikut: (i). Planning (perencanaan) yaitu suatu usaha atau upaya untuk merencanakan kegiatan yang akan

dilaksanakan guna mencapai tujuan yang telah ditetapkan;p (ii). Organizing (mengorganisasikan) yaitu kegiatan yang meliputi penetapan struktur, tugas dan kewajiban, fungsi pekerjaan, dan hubungan antarfungsi; (iii). Actuating (penggerakan) adalah kegiatan yang menggerakkan dan mengusahakan agar para pekerja melakukan tugas dan kewajibannya; dan (iv). Controlling (pengendalian) yaitu evaluasi terhadap seluruh kegiatan sehingga selama perjalanan kegiatan, kelemahannya akan diketahui dengan cepat dan sesegera mungkin dikoreksi.

\subsection{Laporan Keuangan}

Laporan keuangan menurut Myer yang dikutip Munawir (2007:5) adalah dua daftar yang disusun oleh akuntan pada akhir periode untuk suatu perusahaan kedua daftar itu adalah daftar neraca atau daftar posisi keuangan dan daftar pendapatan atau daftar laba rugi. Sedangkan laporan keuangan menurut Raharjo (2005:120), adalah laporan pertanggung jawaban manajer atau pimpinan perusahaan yang dipercayakan kepada pihak-pihak perusahaan yang berkepentingan, di luar perusahaan, pemilik perusahaan, pemerintah, kreditor dan pihak lainnya. Berdasarkan pengertian tersebut di atas, dapat disimpulkan bahwa untuk dapat menentukan posisi keuangan dan hasil usaha serta perkembangan keuangan perusahaan memuaskan atau tidak adalah dengan cara menganalisa laporan keuangan yang dilakukan dengan mempelajari hubungan antara trend dari pos-pos laporan keuangan tersebut. 


\subsection{Analisa Rasio Keuangan}

Menurut Munawir (2007:64), analisa rasio keuangan berfungsi untuk menggambarkan suatu hubungan atau perimbangan (mathematical relationship) antara suatu jumlah tertentu dengan jumlah yang lain. Dengan menggunakan alat analisa berupa rasio, akan dapat menjelaskan atau memberi gambaran kepada penganalisa tentang baik atau buruknya keadaan atau posisi keuangan suatu perusahaan terutama apabila angka rasio tersebut dibandingkan dengan angka rasio pembanding yang digunakan sebagai standar.Angka rasio yang ada dapat digolongkan menjadi dua golongan atau dua kelompok. Golongan pertama adalah berdasarkan sumber data keuangan yang merupakan unsur atau elemen dari angka rasi tersebut dan penggolongan yang kedua adalah didasarkan pada tujuan penganalisa. Berdasarkan sumber datanya, maka angka rasio dapat dibedakan atas: (i). Rasio-rasio neraca (balance sheet ratios), adalah rasio-rasio yang disusun dari data yang berasal dari neraca, misalnya current ratio, acid test ratio, current assets to total assets ratio, current liabilities to total asset ratio dan lain-lain; (ii). Rasio laporan laba rugi (income statement ratios) adalah rasio-rasio yang disusun dari data yang berasal dari Income statement, misalnya gross profit margin, net operating margin,operatingratio dan lain-lain; dan (iii). Rasio-rasio antar laporan (inter statement ratios) adalah rasio-rasio yang disusun dari data yang berasal dari neraca dan data lainnya berasal dari income statement, misalnya assets turn over, inventory turnover, receivables turn over dan lain sebagainya.

Tujuan tiap penganalisa pada umumnya adalah untuk mengetahui tingkat rentabilitas,solvabilitas dan likuiditas dari perusahaan yang bersangkutan, oleh karena itu angka rasio pada dasarnya jugadapat digolongkan antara rasio likuiditas, rasio solvabilitas, rasio rentabilitas dan rasio-rasio lain yang sesuai dengan kebutuhan penganalisa. Misalnya: (i). Non Performing Loan (NPL). NPL menunjukkan rasio pinjaman yang bermasalah terhadap total pinjamannya. Semakin tinggi NPL mengakibatkan semakin tinggi tunggakan bunga kredit yang berpotensi menurunkan pendapatan bunga serta menurunkan perubahan laba (Muljono, 1999); (ii). Biaya Operasi terhadap Pendapatan Operasi (BOPO). BOPO menunjukkan efisiensi bank dalam menjalankan usaha pokoknya terutama kredit berdasarkan jumlah dana yang berhasil dikumpulkan. Dalam pengumpulan dana terutama dana masyarakat (dana pihak ketiga), diperlukan biaya selain biaya bunga (termasuk biaya iklan). Penelitian ini ingin mereplikasi hasil penelitian yang dilakukan oleh (Bahtiar, 2003); (iii). Loan to Deposit Ratio (LDR). LDR mencerminkan kemampuan bank dalam menyalurkan dana pihak ketiga pada Loan/kredit atau sejenis kredit untuk menghasilkan pendapatan atau perubahan laba. Jika dana pihak ketiga tidak tersalur atau iddle money akan mengakibatkan kehilangan kesempatan mendapatkan bunga, pendapatan rendah dan perubahan laba menjadi rendah (Muljono, 1999); (iv). Capital Adequacy Ratio (CAR). CAR diukur dari rasio antara Modal Sendiri (Modal Inti + Modal Pelengkap) terhadap Aktiva Tertimbang Menurut Risiko (ATMR) (Manullang, 2002). Capital Adequacy Ratio (CAR) merupakan rasio permodalan yang menunjukkan kemampuan bank dalam menyediakan dana untuk keperluan pengembangan usaha dan menampung risiko kerugian dana yang diakibatkan oleh kegiatan operasi bank; (v). Net Interest Margin (NIM). NIM menunjukkan kemampuan bank dalam menghasilkan pendapatan dari bunga dengan melihat kinerja bank dalam menyalurkan kredit, mengingat pendapatan operasional bank sangat tergantung dari selisih bunga (spread) dari kredit yang disalurkan. Muljono (1999), menyatakan bahwa bank merupakan lembaga pemberi kredit, maka dalam aktivitasnya sangat berkaitan dengan sifat kredit, pengaturan tata cara dan prosedur pemberian kredit, analisis kredit, penetapan plafon kredit dan pengamanan kredit. Tujuan utama pemberian kredit adalah untuk mendapatkan hasil yang tinggi, dan tujuan yang lain adalah keamanan bank sehingga bank tetap dipercaya oleh masyarakat, hal 
tersebut berdampak pada meningkatnya perubahan laba; (vi). Debt to Equity Ratio (DER). Prihantoro (2003) menyatakan bahwa DER mencerminkan kemampuan perusahaan dalam memenuhi seluruh kewajibannya, yang ditunjukkan oleh berapa bagian modal sendiri yang digunakan untuk membayar hutang secara sistematik. Semakin besar rasio ini menunjukkan semakin besar tingkat ketergantungan perusahaan terhadap pihak eksternal dan semakin besar beban biaya hutang yang harus dibayar perusahaan; (vii). Debt to Total Assets Ratio (DAR). DAR merupakan rasio antara total hutang (total debts) baik hutang jangka pendek (current liability) dan hutang jangka panjang (long term debt) terhadap total aktiva (total assets) baik aktiva lancar (current assets) maupun aktiva tetap (fixed assets) dan aktiva lainnya (other assets). Rasio ini menunjukkan besarnya hutang yang digunakan untuk membiayai aktiva yang digunakan oleh perusahaan dalam rangka menjalankan aktivitas operasionalnya; (viii). Cash Ratio (CR). Menurut Wiagustini (2010), likuditas adalah kemampuan perusahaan dalam memenuhi finansial dalam jangka pendek dengan dana lancar yang tersedia. Dahlan (2001:53), menyatakan bahwa likuditas adalah kemampuan bank untuk memenuhi semua penarikan dana yang dilakukan oleh nasabah, kewajiban yang telah jatuh tempo dan memenuhi permintaan kredit tanpa ada penundaan; (ix). Kualitas Aktiva Produktif (KAP). KAP merupakan salah satu faktor penentu kesehatan Bank. KAP sangat berperan dalam memperoleh tingkat pendapatan bagi bank. Penghimpunan dana dari masyarakat dimaksudkan untuk dijadikan leading perolehan pendapatan, yaitu dengan jalan menambahkan dana tersebut ke dalam aktiva produktif. Yang termasuk aktiva produktif pada bank konvensional adalah penyaluran kredit, surat-surat berharga, penyertaan kredit dan penanaman lainnya (Sudirman, 2009); dan (x). Return on Asset (ROA). Husnan (2009), menyebutkan bahwa ROA adalah rasio untuk mengukur kemampuan aktiva perusahaan memperoleh laba dari operasi perusahaan. Hasibuan (2004:100), menyimpulkan bahwa Return on Assets (ROA) adalah perbandingan (rasio) laba sebelum pajak (earning before tax) selama 12 bulan terakhir terhadap rata-rata volume usaha dalam periode yang sama.

\section{METODOLOGI PENELITIAN}

Metode analisis yang digunakan dalam penelitian ini adalah analisis kinerja keuangan, uji asumsi klasik dengan melakukan uji multikolinearitas, uji autokorelasi serta uji heteroskedastisitas, uji normalitas, analisis regresi berganda, pengujian hipotesis dengan melakukan uji koefisien korelasi (R), uji koefisien determinasi (adjusted R2), uji t (pengujian secara parsial) dan uji F (pengujian simultan). Sementara itu, data yang dipakai dalam penelitian ini adalah data sekunder (secondary data), yang datanya diperoleh secara tidak langsung, artinya data tersebut berupa data yang telah diolah lebih lanjut dan data yang disajikan oleh pihak lain. Menurut Sugiyono (2009:137), menyatakan bahwa data sekunder adalah sumber yang tidak langsung memberikan data kepada pengumpul data, misalnya lewat orang lain atau dokumen. Jenis data yang digunakan dalam penelitian ini adalah:

1. Data Kualitatif adalah data yang berbentuk kata, kalimat, skema, dan gambar. Jenis data kualitatif ini ialah data primer yaitu data yang telah mengalami proses pengolahan oleh sumbernya.

2. Data Kuantitatifadalah data yang disajikan dalam bentuk angka. Data ini menunjukan nilai terhadap besaran atau variabel yang diwakilinya. Sifat data ini adalah data renteng waktu yaitu data yang merupakan hasil pengamatan dalam suatu periode tertentu. 


\subsection{Uji Asumsi Klasik}

Untuk menghindari adanya regresi yang menyesatkan, maka uji asumsi klasik dilakukan dalam penelitian ini, diantaranya uji multikolinearitas, uji heteroskedastisitas, uji autokorelasi dan uji normalitas data. Menurut Ghozali (2007), uji multikolinearitas bertujuan untuk menguji apakah pada model regresi ditemukan adanya korelasi antar variabel independen. Untuk mendeteksi ada tidaknya multikolinearitas dalam model regresi dapat dilihat dari tolerance value atau variance inflation factor (VIF). Sebagai dasar acuannya dapat disimpulkan (i). Jika nilai tolerance $>0,10$ dan nilai VIF $<10$, maka bahwa tidak ada multikolinearitas antar variabel independen dalam model regresi dan (ii). Jika nilai tolerance $<0,10$ dan nilai VIF $>10$, maka bahwa ada multikolinearitas antar variabel independen dalam model regresi. Sementara itu, uji heteroskedastisitas bertujuan untuk menguji apakah dalam model regresi terjadi ketidaksamaan variance dari residual satu pengamatan ke pengamatan lain. Model regresi yang baik adalah yang terjadi homokedastisitas atau tidak terjadi heteroskedastisitas. Uji autokorelasi bertujuan untuk menguji apakah dalam suatu model regresi linear ada korelasi antara kesalahan penggangu pada periode t dengan kesalahan periode t-1 (sebelumnya). Jika terjadi korelasi maka dinamakan ada problem autokorelasi. Model regresi yang baik adalah yang bebas autokorelasi. Sedangkan uji normalitas bertujuan untuk menguji apakah dalam model regresi variabel terikat dan variabel bebas, keduanya mempunyai distribusi normal atau tidak. Model regresi yang baik adalah distribusi data normal atau mendekati normal. Uji ini dilakukan dengan cara melihat penyebaran data (titik) pada sumbu diagonal atau grafik. Apabila data menyebar di sekitar garis diagonal dan mengikuti arah garis diagonal maka model regresi memenuhi asumsi normalitas. Apabila data menyebar jauh dari garis diagonal dan atau tidak mengikuti arah garis diagonal maka model regresi tidak memenuhi asumsi normalitas (Ghozali, 2007).

\subsection{Analisis Regresi Berganda}

Metode analisis yang digunakan adalah model regresi linier berganda yang persamaannya sebagai berikut: $\mathbf{Y}=\mathbf{a}+\boldsymbol{\beta}_{1} \mathbf{X}_{1}+\boldsymbol{\beta}_{2} \mathbf{X}_{2}+\boldsymbol{\beta}_{3} \mathbf{X}_{3}+\boldsymbol{\beta}_{4} \mathbf{X}_{4}+\boldsymbol{\beta}_{5} \mathbf{X}_{5}+\boldsymbol{\beta}_{6} \mathbf{X}_{6}+\boldsymbol{\beta}_{7} \mathbf{X}_{7}+\boldsymbol{\beta}_{8} \mathbf{X}_{8}+\boldsymbol{\beta}_{9} \mathbf{X}_{9}+\mathbf{e}$ dimana:

$\mathrm{Y}=\mathrm{ROA}, \mathrm{a}=$ konstanta, $\mathrm{X}_{1}=\mathrm{NPL}, \mathrm{X}_{2}=\mathrm{BOPO}, \mathrm{X}_{3}=\mathrm{CAR}, \mathrm{X}_{4}=\mathrm{LDR}, \mathrm{X}_{5}=\mathrm{NIM}, \mathrm{X}_{6}=\mathrm{DER}$, $\mathrm{X}_{7}=\mathrm{DAR}, \mathrm{X}_{8}=\mathrm{CR}, \mathrm{X}_{9}=\mathrm{KAP}, \beta 1, \ldots, \beta \mathrm{n}=$ Koefisien regresi, $\mathrm{e}=$ error term

Nilai koefisien regresi disini sangat menentukan sebagai dasar analisis, mengingat penelitian ini bersifat fundamental method. Hal ini berarti jika koefisien b bernilai positif $(+)$ maka dapat dikatakan terjadi pengaruh searah antara variabel independen dengan variabel dependen, setiap kenaikan nilai variabel independen akan mengakibatkan kenaikan variabel dependen.

Pengujian untuk mengetahui ada atau tidaknya hubungan antara variabel independen dengan variabel dependen, pada pengujian ini dapat dilihat apakah hubungan antara varibel tersebut kuat atau lemah. Menurut Ghozali (2011), dalam menentukan hubungan tersebut dapat dilihat melalui hasil koefisien regresi yaitu antara 0 sampai dengan 1 . Nilai 0 tersebut menunjukkan tidak ada hubungan sedangkan nilai 1 menunjukkan adanya hubungan yang sempurna. Apabila nilai $\mathrm{R}=0,5$ atau $\mathrm{R}>0,5$ maka menunjukkan hubungan yang kuat dan apabila nilai $\mathrm{R}<0,5$ maka menunjukkan hubungan yang lemah. Selanjutnya adalah pengujian untuk mengukur seberapa jauh kemampuan model dalam menerangkan variasi variabel dependen yaitu dengan menggunakan nilai $\mathrm{R}^{2}$ dan nilai Adjusted $R^{2}$. Menurut Ghozali (2011), bahwa nilai Adjusted $R^{2}$ berkisar antara 0 sampai dengan 1, apabila Adjusted $R^{2}$ mendekati 1 menunjukkan 
bahwa hampir semua variabel-variabel independent yang terdapat dalam model dapat menjelaskan informasi yang dibutuhkan untuk memprediksi variabel dependent.

\section{PEMBAHASAN}

Pembahasan ini penulis menyajikan data NPL, BOPO, CAR,LDR, NIM, DER,DAR, CR, KAP dan ROA periode bulan April 2011 sampai dengan Desember 2013 (per bulan).

Periode bulan April 2011 sampai dengan Desember 2013 (per bulan)

\begin{tabular}{|c|c|c|c|c|c|c|c|c|c|c|c|c|}
\hline NO. & \multicolumn{2}{|c|}{ BULAN } & NPL & BOPO & CAR & LDR & NIM & DER & DAR & CR & KAP & ROA \\
\hline 1 & April & 2011 & 1.39 & 89.47 & 19.56 & 71.61 & 2.30 & 15.97 & 0.90 & 12.95 & 0.75 & 3.56 \\
\hline 2 & Mei & 2011 & .38 & 87.50 & 8.23 & 72.71 & 3.49 & 15.82 & 0.89 & 8.98 & 0.74 & 3.33 \\
\hline 3 & Juni & 2011 & .45 & 80.23 & 5.72 & 68.19 & 4.86 & 12.67 & 0.89 & 9.45 & 0.78 & 3.71 \\
\hline 4 & Juli & 2011 & .42 & 78.20 & 9.90 & 66.04 & 5.88 & 17.51 & 0.90 & 10.65 & .08 & 3.40 \\
\hline 5 & gustus & 2011 & 1.51 & 82.05 & 12.26 & 63.78 & 7.41 & 13.02 & 0.89 & 13.45 & 0.81 & 3.58 \\
\hline 6 & eptember & 2011 & 1.49 & 86.49 & 13.46 & 62.51 & 8.15 & 13.49 & 0.89 & 12.96 & 0.80 & 1.95 \\
\hline 7 & ktober & 2011 & 1.48 & 86.66 & 15.23 & 64.24 & 9.31 & 13.22 & 0.89 & 13.25 & 0.79 & 3.87 \\
\hline 8 & pember & 2011 & 1.43 & 86.04 & 4.32 & 66.20 & 10.23 & 13.28 & 0.88 & 8.78 & 0.77 & 2.46 \\
\hline 9 & Desember & 2011 & 1.35 & 84.05 & 15.67 & 70.24 & 11.95 & 13.29 & 0.88 & 9.45 & 0.73 & 1.86 \\
\hline 10 & Januari & 2012 & 3.86 & 82.62 & 10.16 & 73.84 & 1.34 & 16.57 & 0.94 & 12.25 & 2.49 & 1.76 \\
\hline 11 & ari & 2012 & 2.47 & 82.49 & 0.62 & 72.96 & 2.26 & 17.14 & 0.93 & 8.82 & 1.46 & 1.75 \\
\hline 12 & Maret & 2012 & 1.52 & 84.89 & 10.85 & 73.06 & 3.66 & 17.16 & 0.92 & 13.03 & 1.29 & 1.78 \\
\hline 13 & April & 2012 & 2.56 & 79.84 & 1.06 & 74.20 & 4.60 & 13.75 & 0.92 & 10.15 & 0.68 & 1.76 \\
\hline 14 & Mei & 2012 & 1.26 & 83.31 & 15.67 & 73.77 & 12.28 & 13.34 & 0.86 & 10.26 & 0.68 & 2.75 \\
\hline 15 & Juni & 2012 & 1.37 & 71.02 & 11.60 & 66.90 & 3.57 & 13.53 & 0.87 & 10.78 & 0.74 & 3.87 \\
\hline 16 & Juli & 2012 & 1.38 & 85.09 & 0.56 & 66.44 & 10.94 & 13.77 & 0.88 & 11.02 & 0.74 & 1.96 \\
\hline 17 & Agustus & 2012 & 2.61 & 77.35 & 10.93 & 70.10 & 3.93 & 14.27 & 0.92 & 11.71 & 1.24 & 1.86 \\
\hline 18 & ptember & 2012 & 1.42 & 82.63 & 9.45 & 64.13 & 6.04 & 6.46 & 0.81 & 11.25 & 0.76 & 3.40 \\
\hline 19 & tober & 2012 & 4.30 & 81.79 & 0.78 & 69.67 & 9.12 & 14.56 & 0.92 & 10.73 & 2.32 & 1.91 \\
\hline 20 & opember & 2012 & 1.35 & 70.56 & 11.58 & 66.84 & 4.64 & 7.03 & 0.82 & 10.50 & 0.73 & 2.87 \\
\hline 21 & Desember & 2012 & 1.27 & 65.71 & 15.67 & 70.62 & 1.23 & 13.81 & 0.86 & 11.32 & 0.68 & 3.35 \\
\hline 22 & nuari & 2013 & 1.32 & 66.55 & 5.67 & 68.29 & 2.26 & 13.84 & 0.86 & 10.65 & 0.71 & 2.87 \\
\hline 23 & bruari & 2013 & 2.26 & 80.25 & 10.90 & 71.33 & 10.05 & 14.68 & 0.91 & 10.88 & 1.29 & 1.97 \\
\hline 24 & Maret & 2013 & 4.71 & 81.25 & 10.73 & 68.24 & 7.94 & 14.80 & 0.92 & 12.35 & 2.19 & 1.88 \\
\hline 25 & April & 2013 & 3.22 & 74.30 & 9.25 & 71.56 & 5.68 & 18.95 & 0.93 & 10.32 & 1.52 & 1.82 \\
\hline 26 & Mei & 2013 & 1.27 & 79.07 & 12.44 & 69.43 & 12.45 & 14.77 & 0.91 & 16.64 & 0.48 & 4.67 \\
\hline 27 & Juni & 2013 & 2.08 & 77.35 & 15.03 & 67.08 & 5.69 & 14.92 & 0.90 & 20.23 & 0.77 & 4.65 \\
\hline 28 & Juli & 2013 & 1.16 & 76.91 & 12.24 & 73.31 & 12.72 & 14.94 & 0.90 & 20.53 & 0.42 & 4.72 \\
\hline 29 & Agustus & 2013 & 1.77 & 73.94 & 14.25 & 69.29 & 93 & 14.97 & 0.90 & 18.38 & 0.86 & 5.33 \\
\hline 30 & September & 2013 & 2.12 & 78.33 & 11.17 & 68.47 & 11.07 & 15.24 & 0.91 & 11.06 & 1.12 & 4.17 \\
\hline 31 & Oktober & 2013 & 1.45 & 73.59 & 13.70 & 67.71 & 3.34 & 15.49 & 0.90 & 19.61 & 0.73 & 5.35 \\
\hline 32 & Nopember & 2013 & 1.17 & 75.72 & 14.94 & 67.84 & 1.19 & 15.71 & 0.90 & 19.67 & 0.64 & 4.94 \\
\hline 33 & Desember & 2013 & 1.19 & 74.16 & 15.67 & 65.95 & 2.16 & 15.77 & 0.90 & 21.47 & 0.64 & 5.25 \\
\hline
\end{tabular}

Sumber: Data diolah. 


\subsection{ANALISIS}

Berdasarkan data pengaruh NPL, BOPO, CAR, LDR, NIM, DER, DAR, CR, KAP terhadap ROA periode bulan April 2011 sampai dengan Desember 2013 (per bulan), kemudian diolah dengan menggunakan SPSS 20.0., didapat hasil sebagai berikut:

Tabel 4.2.

Deskriptif Statistik

\begin{tabular}{|l|c|c|c|c|}
\hline \multicolumn{1}{|c|}{ Variabel } & Minimum & Maksimum & Mean & $\begin{array}{c}\text { Standard } \\
\text { Deviation }\end{array}$ \\
\hline NPL & 1,16 & 4,71 & 1,8785 & 0,92290 \\
\hline BOPO & 65,71 & 89,47 & 79,3761 & 5,89063 \\
\hline CAR & 9,25 & 19,90 & 13,3112 & 2,83385 \\
\hline LDR & 62,51 & 74,20 & 68,9864 & 3,20446 \\
\hline NIM & 1,19 & 12,72 & 6,2324 & 3,69946 \\
\hline DER & 6,46 & 18,95 & 14,3558 & 2,44785 \\
\hline DAR & 0,81 & 0,94 & 0,8939 & 0,02872 \\
\hline CR & 8,78 & 21,47 & 12,8342 & 3,78319 \\
\hline KAP & 0,08 & 2,49 & 0,9524 & 0,52931 \\
\hline ROA & 1,72 & 5,35 & 3,1624 & 1,22676 \\
\hline Jumlah & \multicolumn{5}{|l}{33} \\
Sampel & \multicolumn{5}{|l}{3} \\
\hline
\end{tabular}

Sumber: data diolah, SPSS

Berdasarkan tabel 4.2. diketahui bahwa dari 33 sampel diketahui bahwa nilai standar deviasi mendekati angka 0 maka data tidak bervariasi dan sebaliknya jika menjauhi angka 0 atau menjauhi angka 1 maka data bervariasi.

\subsubsection{Uji Normalitas}

\section{Hasil Uji Normalitas}

\begin{tabular}{|c|c|c|c|c|c|c|c|c|c|c|c|}
\hline & & NPL & BOPO & CAR & LDR & NIM & DER & DAR & $\mathrm{CR}$ & KAP & ROA \\
\hline$\overline{\mathrm{N}}$ & & 33 & 33 & 33 & 33 & 33 & 33 & 33 & 33 & 33 & 33 \\
\hline \multirow[t]{2}{*}{ Normal Parameters } & Mean & 1.8785 & 79.3761 & 13.3112 & 68.9864 & 6.2324 & 14.3558 & .8939 & 12.8342 & .9524 & 3.1624 \\
\hline & Std. Deviation & .92290 & 5.89063 & 2.83385 & 3.20446 & 3.69946 & 2.44785 & . 02872 & 3.78319 & .52931 & 1.22676 \\
\hline \multirow{3}{*}{$\begin{array}{l}\text { Most Extreme } \\
\text { Differences }\end{array}$} & Absolute & .318 & .083 & 151 & .090 & .130 & .202 & .173 & .223 & .303 & 198 \\
\hline & Positive & .318 & .054 & .151 & .079 & .130 & .103 & .091 & .223 & .303 & .198 \\
\hline & Negative & -218 & -.083 & -.081 & -.090 & -.091 & -202 & -.173 & -142 & -.187 & -.125 \\
\hline Kolmogorov-Smirnov Z & & 1.826 & .478 & .869 & .514 & .744 & 1.159 & .992 & 1.282 & 1.741 & 1.138 \\
\hline Asymp. Sig. (2-tailed) & & .060 & .976 & .437 & .954 & .637 & .136 & .278 & .075 & .100 & .150 \\
\hline
\end{tabular}

Sumber: data diolah, SPSS

Berdasarkan tabel diatas bahwa apabila nilai probabilitas atau Asyimp. Sig (2-tailed)> 0,05, maka distribusi dikatakan normal. Mengacu pada ketentuan ini, maka variabel NPL, BOPO, CAR, LDR, NIM, DER, DAR, CR, KAP dan ROA yang nilai probabilitasnya mencapai besaran 0,060, 0,976, 0,437, 0,954, 0,637, 0,136, 0,278, 0,075, 0,100, dan 0,150 ternyata lebih besar dari pada nilai probabilitas 0,05 maka dengan demikian variabel NPL, BOPO, CAR, LDR, NIM, DER, DAR, CR, KAP dan ROA dikatakan berdistribusi normal.Sehingga dapat dilakukan pengujian selanjutnya yaitu pengujian asumsi klasik. 


\subsubsection{Uji Asumsi Klasik}

Uji asumsi klasik terdiri dari Uji Multikolinearitas, Uji Autokorelasi dan Uji Heteroskedastisitas. Pengujian ini dimaksudkan untuk memastikan bahwa model yang diperoleh benar-benar memenuhi asumsi dasar dalam analisis regresi yang meliputi asumsi-asumsi: terjadi normalitas, tidak terjadi multikolinearitas, tidak terjadi autokorelasi, dan tidak terjadi heteroskedastisitas, serta untuk mengetahui apakah model regresi benar-benar menunjukkan tingkat yang signifikan dan representatif.

\subsubsection{Uji Multikolinearitas}

Uji Multikolinearitas dapat dilihat dari nilai tolerance dan VIF (Variance Inflation Factor). Kedua ukuran ini menunjukkan setiap variabel bebas yang dijelaskan oleh variabel bebas lainnya. Semakin tinggi VIF (Variance Inflation Factor) mengindikasikan bahwa multikolinearitas diantara variabel bebas akan semakin tinggi dimana standar nilai adalah 10, sedangkan tolerance mengukur variabelitas variabel bebas terpilih yang tidak dapat dijelaskan oleh variabel bebas lainnya. Nilai yang umum dipakai adalah nilai tolerance sebesar 0.1 atau sama dengan nilai VIF 10.

Rumus yang digunakan dalam multikolinearitas adalah:

$$
\operatorname{VIF}=\frac{\operatorname{VAR}\left(\beta_{\mathrm{j}}\right) \sum \mathrm{X}_{\mathrm{j}}}{\sigma^{2}}
$$

Hipotesa yang digunakan dalam uji multikolinearitas adalah:

Ho : Tidak ada Multikolinearitas, Ha : Ada Multikolinearitas

Dasar pengambilan keputusannya adalah:

Jika VIF $>10$ atau jika tolerance $<0.1$ maka Ho ditolak dan Ha diterima.

Tabel 4.4.

Hasil Pengujian Multikolinearitas

\begin{tabular}{|l|c|c|c|}
\hline \multicolumn{1}{|c|}{ Variabel } & Tolerance & VIF & Keputusan \\
\hline NPL & 0,124 & 8,053 & Tidak terjadi multikolinearitas \\
\hline BOPO & 0,493 & 2,027 & Tidak terjadi multikolinearitas \\
\hline CAR & 0,412 & 2,428 & Tidak terjadi multikolinearitas \\
\hline LDR & 0,707 & 1,415 & Tidak terjadi multikolinearitas \\
\hline NIM & 0,668 & 1,498 & Tidak terjadi multikolinearitas \\
\hline DER & 0,153 & 6,555 & Tidak terjadi multikolinearitas \\
\hline DAR & 0,107 & 9,321 & Tidak terjadi multikolinearitas \\
\hline CR & 0,662 & 1,512 & Tidak terjadi multikolinearitas \\
\hline CAP & 0,128 & 7,828 & Tidak terjadi multikolinearitas \\
\hline \multicolumn{2}{|c|}{ Sumber: data diolah, SPSS }
\end{tabular}

Jika VIF $<10$ atau jika tolerance $>0.1$ maka Ho diterima dan Ha ditolak. Ha diterima menunjukan adanya multikolinearitas dalam model regresi sedangkan jika Ha ditolak menunjukkan tidak ada multikolineritas antar variabel bebas dalam model regresi. Berdasarkan tabel 4.4., diketahui nilai tolerance yang mendekati angka 1 dan nilai VIF (Variance Inflation Factor) yang berada dibawah nilai 10 sehingga dapat disimpulkan bahwa tidak terjadi multikolinearitas artinya tidak terjadinya korelasi/hubungan diantara variabel independen. Sehingga pengujian selanjutnya dapat dilanjutkan, karena telah memenuhi syarat pengujian asumsi klasik dilanjutkan untuk pengujian autokorelasi. 


\subsubsection{Uji Autokorelasi}

Uji autokorelasi bertujuan untuk menguji apakah dalam suatu model regresi linier terdapat korelasi antara kesalahan pengganggu pada periode tertentu dengan kesalahan pengganggu pada periode sebelumnya. Autokorelasi sering timbul pada penelitian time series karena gangguan pada individu/kelompok cenderung mempengaruhi gangguan pada individu/kelompok yang sama pada periode berikutnya. Formula yang digunakan untuk menghitung statistik Durbin-Watson (DW test). Rumus yang digunakan adalah: $\mathrm{DW}=\frac{\sum \mu_{\mathrm{t}}^{2}+\sum \mu_{\mathrm{t}-1}^{2}-2 \sum \mu_{\mathrm{t}} \mathrm{x} \mu_{\mathrm{t}_{\mathrm{i}}-1}}{\sum \mu_{\mathrm{t}}^{2}}$

Keterangan:

DW $=$ statistik Durbin-Watson, it=nilai residual pada periode $t, \mu_{t-1}=$ nilai residual pada periode $t-1$ Uji autokorelasi dapat dilakukan dengan melihat nilai DW (Durbin-Watson).

Hipotesis yang digunakan adalah:

Ho : Tidak ada Autokorelasi

Ha : Ada Autokorelasi

\section{Hasil Pengujian Autokorelasi}



Berdasarkan gambar disamping pengujian autokorelasi diatas nilai Durbin-Watson berada diantara nilai du $\leq \mathrm{DW} \leq 4$-du atau $1,567 \leq 2,066 \leq 2,433$, sehingga dapat disimpulkan tidak terjadi autokorelasi. Sehingga dapat dilanjutkan kepadaujiheteroske-dastisitas. Berikut ini hasil pengujian ada atau tidaknya heteroskedastisitas dalam model yang dibuat.

\subsubsection{Uji Heteroskedastisitas}

Berdasarkan hasil pengolahan data Uji Heteroskedastisitas dapat dilihat pada tabel dibawah ini: 


\section{Hasil Uji \\ Heteroskedastisitas dengan Scatterplot}

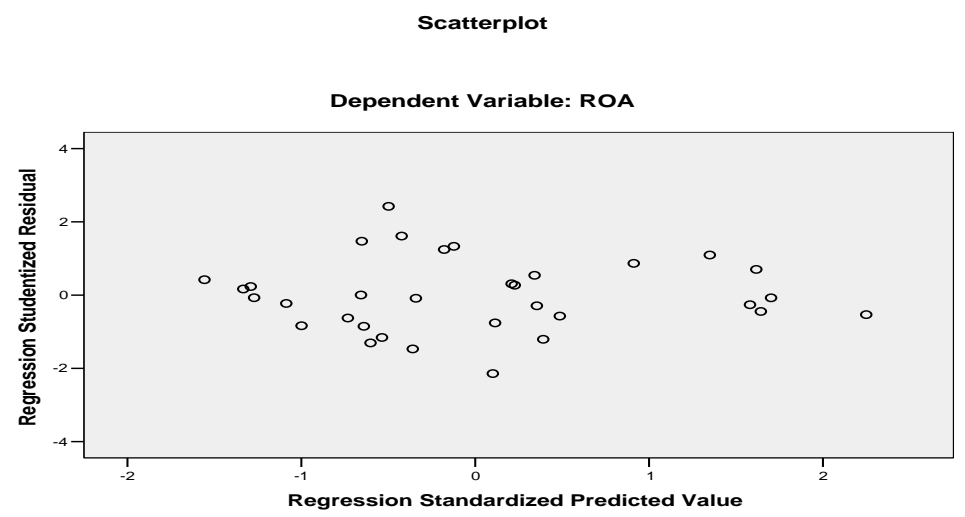

Dari gambar di disamping terlihat bahwa titik-titik menyebar secara acak serta tersebar baik di atas maupun di bawah angka 0 pada sumbu Y. Hal ini dapat disimpulkan bahwa tidak terjadi heteroske-dastisitas pada model regresi, sehingga model regresi layak dipakai untuk memprediksi ROA berdasarkan masukkan variabel independen NPL, BOPO, CAR, LDR, NIM, DER,DAR, CR dan KAP.

\subsubsection{Uji Koefisien Determinasi $\left(\mathbf{R}^{2}\right)$}

\section{Hasil Uji Koefisien Determinasi}

\begin{tabular}{|c|c|c|}
\hline $\mathbf{R}$ & $\mathbf{R}^{2}$ & Adjusted $\mathbf{R}^{2}$ \\
\hline 0,874 & 0,764 & 0,672 \\
\hline
\end{tabular}

Sumber: data diolah, SPSS

Berdasarkan tabel diatas diketahui nilai $\mathrm{R}$ sebesar 0,874 artinya variabel NPL, BOPO,CAR, LDR,NIM, DER, DAR, CR dan KAP memiliki hubungan yang sangat kuat dengan variabel ROA. Sedangkan nilai adjusted $\mathrm{R}^{2}$ sebesar 0,672 atau sebesar 67,2\% artinya besar kontribusi pengaruh dari variabel NPL, BOPO, CAR, LDR, NIM, DER, DAR, CR dan KAP terhadap ROA sebesar $67,2 \%$ sedangkan sisanya sebesar $32,8 \%$ dipengaruhi oleh variabel lain yang tidak dimasukkan dalam model.

\subsubsection{Uji F (Pengujian Simultan)}

Digunakan untuk menguji apakah secara bersama-sama seluruh variabel independen mempunyai pengaruh yang signifikan terhadap variabel dependen. Dasar pengambilan keputusan untuk pengujian secara simultan ini adalah dengan membandingkan $p$-value dengan nilai sebesar0,05. Jika $p$-value < alpha 0,05 maka Ho ditolak dan sebaliknya jika p-value>alpha 0,05 maka Ho diterima. 
Hasil Uji F

Sumber: data diolah, SPSS

\begin{tabular}{|c|c|c|c|}
\hline $\mathbf{F}_{\text {tabel }}$ & $\mathbf{F}_{\text {hitung }}$ & Significance & Keputusan \\
\hline 2,930 & 8,278 & 0,000 & Ho ditolak \\
\hline
\end{tabular}

Berdasarkan tabel diatas diketahui nilai $\mathrm{F}_{\text {hitung }}>\mathrm{F}_{\text {tabel }}$ atau 8,278 $>$ 2,930 dan nilai signifikansi < 0,05 atau 0,000 $<0,05$ sehingga dapat disimpulkan secara bersama-sama variabel NPL, BOPO, CAR,LDR, NIM, DER, DAR, CR dan KAP mempengaruhi ROA.

\subsubsection{Uji t (Pengujian Secara Parsial)}

Untuk menguji koefisien regresi dilakukan pengujian secara parsial untuk melihat signifikansi dari pengaruh masing-masing variabel independen terhadap variabel dependen dengan mengasumsikan variabel lain adalah konstan. Dasar pengambilan keputusan untuk pengujian secara parsial ini adalah jika $p$-value $<$ alpha 0,05 maka Ho ditolak dan sebaliknya jika $p$-value $>$ alpha 0,05 maka Ho diterima.

Rumusnya adalah:

$$
t=r \sqrt{\frac{n-2}{1-r^{2}}} \text { atau } t_{\text {tabel }}=\left(\frac{\alpha}{2}, n-2\right)
$$

Tabel 4.8.

Hasil Uji t

\begin{tabular}{|l|c|c|c|c|}
\hline \multicolumn{1}{|c|}{ Variabel } & $\mathbf{t}_{\text {tabel }}$ & $\mathbf{t}_{\text {hitung }}$ & Sig & Keputusan \\
\hline NPL & $-2,019$ & $-0,803$ & 0,430 & Ho diterima \\
\hline BOPO & $-2,019$ & $-1,516$ & 0,143 & Ho diterima \\
\hline CAR & 2,019 & 1,787 & 0,087 & Ho diterima \\
\hline LDR & $-2,019$ & $-0,657$ & 0,518 & Ho diterima \\
\hline NIM & 2,019 & 0,405 & 0,689 & Ho diterima \\
\hline DER & $-2,019$ & $-0,606$ & 0,551 & Ho diterima \\
\hline DAR & 2,019 & 0,370 & 0,715 & Ho diterima \\
\hline CR & 2,019 & 5,011 & 0,000 & Ho ditolak \\
\hline KAP & 2,019 & 0,071 & 0,944 & Ho diterima \\
\hline
\end{tabular}

Sumber: data diolah, SPSS

Berdasarkan table disamping, dimana hipotesa Ho yang ditolak adalah CR pada Hipotesa 8, sedangkan Hipotesa yang lainnya Ho diterima:

\section{Hipotesis 8}

\section{Pengaruh CR terhadap ROA}

Ho : Tidak terdapat pengaruh antara CR terhadap ROA.

Ha8 : Terdapat pengaruh antara CR terhadap ROA.

Dari pengujian regresi dengan melihat tabel Coefficients, diketahui $p$-value untuk hipotesa 8 adalah $0,000<$ alpha 0,05 dan $t_{\text {hitung }}>\mathrm{t}_{\text {tabel }}$ atau 5,011 $>2,019$ maka Ho ditolak. Artinya terdapat pengaruh secara signifikan antara CR terhadap ROA. 


\section{SIMPULAN, SARAN DAN IMPLIKASI}

\subsection{SIMPULAN}

Berdasarkan hasil penelitian dan pembahasan yang telah dikemukakan sebelumnya, maka diperoleh kesimpulan sebagai berikut:

1. Hasil uji secara partial variabel NPL dengan nilai signifikan sebesar $0,430>a l p h a 0,05$ dan $\mathrm{t}_{\text {hitung }}<\mathrm{t}_{\text {tabel }}$ atau $-0,803<-2,019$ Ho diterima. Artinya tidak terdapat pengaruh secara signifikan antara NPL terhadap ROA.

2. Hasil uji secara partial variabel BOPO dengan nilai signifikan sebesar 0,143 >alpha 0,05 dan $\mathrm{t}_{\text {hitung }}<\mathrm{t}_{\text {tabel }}$ atau $-1,516<-2,019$ Ho diterima. Artinya tidak terdapat pengaruh secara signifikan antara BOPO terhadap ROA.

3. Hasil uji secara partial variabel CAR dengan nilai signifikan sebesar 0,087 >alpha 0,05 dan $\mathrm{t}_{\text {hitung }}<\mathrm{t}_{\text {tabel }}$ atau $1,787<2,019$ Ho diterima. Artinya tidak terdapat pengaruh secara signifikan antara CAR terhadap ROA.

4. Hasil uji secara partial variabel LDR dengan nilai signifikan sebesar 0,518 >alpha 0,05 dan $t_{\text {hitung }}<t_{\text {tabel }}$ atau $-0,657<-2,019$ Ho diterima. Artinya tidak terdapat pengaruh secara signifikan antara LDR terhadap ROA.

5. Hasil uji secara partial variabel NIM dengan nilai signifikan sebesar 0,689 >alpha 0,05 dan $\mathrm{t}_{\text {hitung }}<\mathrm{t}_{\text {tabel }}$ atau 0,405<2,019 Ho diterima. Artinya tidak terdapat pengaruh secara signifikan antara NIM terhadap ROA.

6. Hasil uji secara partial variabel DER dengan nilai signifikan sebesar 0,551 >alpha 0,05 dan $\mathrm{t}_{\text {hitung }}<\mathrm{t}_{\text {tabel }}$ atau $-0,606<-2,019 \mathrm{Ho}$ diterima. Artinya tidak terdapat pengaruh secara signifikan antara DER terhadap ROA.

7. Hasil uji secara partial variabel DAR dengan nilai signifikan sebesar $0,715>$ alpha 0,05 dan $\mathrm{t}_{\text {hitung }}<\mathrm{t}_{\text {tabel }}$ atau 0,370<2,019 Ho diterima. Artinya tidak terdapat pengaruh secara signifikan antara DAR terhadap ROA.

8. Hasil uji secara partial variabel CR dengan nilai signifikan sebesar $0,000<a l p h a 0,05$ dan $\mathrm{t}_{\text {hitung }}>\mathrm{t}_{\text {tabel }}$ atau 5,011>2,019 Ho ditolak. Artinya terdapat pengaruh secara signifikan antara CR terhadap ROA.

9. Hasil uji secara partial variabel KAP dengan nilai signifikan sebesar 0,944 >alpha 0,05 dan $\mathrm{t}_{\text {hitung }}<\mathrm{t}_{\text {tabel }}$ atau $0,071<2,019$ Ho diterima. Artinya tidak terdapat pengaruh secara signifikan antara KAP terhadap ROA.

10. Hasil uji secara simultan dengan nilai $\mathrm{F}_{\text {hitung }}>\mathrm{F}_{\text {tabel }}$ atau 8,278 $>2$,930dan nilai signifikansi $<$ 0,05 atau $0,000<0,05$ sehingga dapat disimpulkan secara bersama-sama variabel NPL, BOPO, CAR, LDR, NIM, DER, DAR, CR dan KAP mempengaruhi ROA.

\subsection{SARAN-SARAN}

Dari penelitian yang dilakukan bahwa Cash Ratio (CR) berpengaruh signifikan terhadap Return on Asset (ROA), dimana Cash Ratio (CR) merupakan faktor dominan yang akan memiliki dampak bagi peningkatan kinerja keuangan bank. Manajemen diharapkan agar dapat mengelolah danacash dan cash equivalent yang banyak tersimpan untuk dialokasikan kedalam aktiva produktif yang dapat menghasilkan keuntungan dari pendapatan bunga yang diproksikan dalam rasio Return on Asset (ROA). Dan penambahan variabel independen dalam penelitian mendatang diperlukan, seperti penambahan variabel Cadangan Kerugian Penurunan Nilai (CKPN) dan faktor-faktor lain diluar model regresi yang dianalisa. 


\subsection{IMPLIKASI HASIL PENELITIAN}

\subsubsection{Implikasi Teoritis}

Secara umum hasil penelitian ini menunjukkan konsistensi dengan hasil-hasil penelitian sebelumnya, dimana model yang dibangun berdasarkan indikator-indikator keuangan dalam bentuk rasio NPL, BOPO, CAR, LDR, NIM, DER, DAR, CR dan KAP dapat digunakan untuk mengetahui kinerja keuangan Bank Perkreditan Rakyat (BPR).

\subsubsection{Implikasi Kebijakan Manajerial}

Hasil penelitian ini memperlihatkan bukti empiris manfaat rasio keuangan yang merupakan proksi dari alat analisis kinerja keuangan Bank Perkreditan Rakyat (BPR) dalam memprediksi kondisi keuangan Bank Perkreditan Rakyat (BPR). Rasio NPL, BOPO, CAR, LDR, NIM, DER, DAR, CR, KAP dan rasio ROA sebagai proksi faktor earnings yang dapat digunakan untuk memprediksikan kondisi bermasalah dalam waktu satu dan dua tahun kedepan serta untuk menghindari kinerja keuangan yang buruk.

\section{DAFTAR PUSTAKA}

Ali, Masyud. 2006. Manajemen Risiko: Strategi Perbankan dan Dunia Usaha Menghadapi Tantangan Globalisasi Bisnis. Rajawali Pers. Jakarta.

Athoillah,H.M. Anton. 2010. Dasar-DasarManajemen, Cetakan Pertama. Penerbit CV. Pustaka Setia. Bandung.

Bahtiar, Usman. 2003. Analisis Rasio Keuangan Dalam Memprediksi Perubahan Laba Pada Bank-Bank di Indonesia. Media Riset Bisnis dan Manajemen. Vol.3, No.1, April2003, pp.59-74.

Dahlan, Siamat. 2001. Manajemen Lembaga Keuangan. Fakultas Ekonomi Universitas Indonesia. Jakarta.

Ghozali, Imam. 2007. Aplikasi Analisis Multivariate Dengan Program SPSS. BP Universitas Diponogoro, Semarang.

Ghozali, Imam. 2011. Aplikasi Analisis Multivariate Dengan Program IBM SPSS 19. Edisi Kelima. Universitas Diponegoro. Semarang.

Hasibuan, Malayu SP. 2004. Manajemen Sumber Daya Manusia. Cetakan Ketujuh edisi revisi. PenerbitBumi Aksara.Jakarta.

Husnan, Suad, 2009. Dasar-Dasar Teori Portofolio \& Analisis Sekuritas, Penerbit UPP STIM YKPN. Yogyakarta.

Manullang, 2002. Manajemen Sumber Daya Manusia, Edisi Kesebelas. Penerbit Ghalia Indonesia. Jakarta.

Muljono, Teguh Pudjo. 1999. Aplikasi Akuntansi Manajemen Dalam Praktik Perbankan, Edisi 3, BPFE. Yogyakarta.

Munawir. 2007. AnalisaLaporan Keuangan, Cetakan Keempat belas, Edisi keempat. Penerbit Liberty. Yogyakarta.

Prihantoro. 2003. Estimasi Pengaruh Dividen Payout Ratio pada Perusahaan Publik di Indonesia. Jurnal Ekonomi dan Bisnis No.1 Jilid 8.

Raharjo, Budi. 2005. Laporan Keuangan Perusahaan, seri membaca, memahami, menganalisis, Cetakan Pertama, Gajah Mada, Yogyakarta.

Stoner,James A.F. 1996. Manajemen (terjemahan). Penerbit Erlangga. Jakarta.

Sudirman, I Wayan. 2009. Manajemen Perbankan. Edisi Pertama. Penerbit Balai Pustaka. Denpasar. 
Sugiyono. 2009. Metode Penelitian Kuantitatif, Kualitatif dan R\&D. Penerbit Alfabeta. Bandung. Wiagustini, Ni luh Putu. 2010. Dasar-Dasar Manajemen Keuangan. Udayana University Press. Denpasar.

Williams, Chuck. 2001. Manajemen (terjemahan). Penerbit Salemba Empat. Jakarta. 